Vol. II. No 22017

\title{
AMERICAN POSTMODERN POETIC TEXTS: IN SEARCH OF RHYTHMICITY
}

\author{
Inna Zabuzhanska
}

Zabuzhanska, I. (2017). American postmodern poetic texts: in search of rhythmicity. In Lege artis. Language yesterday, today, tomorrow. The journal of University of SS Cyril and Methodius in Trnava. Warsaw: De Gruyter Open, 2017, vol. II (2), December 2017, p. 445-481. DOI: 10.1515/lart2017-0021 ISSN 2453-8035

Abstract: This paper highlights the results of the experimental phonetic research on American postmodern poetic texts, voiced by their authors. The acoustic analysis of fundamental frequency, duration, and intensity of rhythmic groups proves their rhythm-creating ability. Arrhythmicity is seen as a means of creating the effect of defeated expectancy, emphasizing those speech fragments, which are crucial in the decoding of the author's intention.

Key words: rhythm, rhythmic group, poetic text, postmodernism, stress, pitch, intensity, duration.

\section{Introduction}

Rhythmicity as a fundamental regularity has been brought to attention since ancient times. The concept of 'rhythm' is common in descriptions of music, poetry, sculpture, and speech. The notion of speech rhythm was raised by a number of linguists, in particular phoneticians (Abercrombie 1967; Crystal 1987; Esser 2011; Nespor 1990; O'Connor 1977; Roach 1991). Rhythmic peculiarities of voiced poetic texts repeatedly attracted the attention of linguists (Карпиченкова 1981; Attridge 1995; Nell 1993; Suppes 2009). Nevertheless, their area of research revolved around rhythmic structure as a component of the inherent metric organization of the poems.

\section{The notion of speech rhythm}

The term 'speech rhythm' itself and the constituents of speech rhythm have had a long and controversial discussion on their record: "If we ask what in more detail are the 
features that determine or suggest rhythm in English, we dislodge a stone that will bring an avalanche of diverse answers on us" (Harding 2010: 8).

The notion of speech rhythm has been given in a narrow and broad sense. First and foremost, the definitions of speech rhythm date back to ancient times when Greek and Roman philosophers tried to understand its essence. Cicero (May \& Wisse 2001: 45), for instance, was sure that:

"...in all sounds and utterances rhythm is understood as the quality of having certain beats and of being measurable by regular intervals...it is natural for the human ear to measure the rhythm of the sounds that are produced by a voice, and that this is impossible if they don't have any rhythm; rhythm is the product of separation, of a beat at regular, or often varying intervals".

Oxford English Dictionary (1989) gives the following definition of speech rhythm: "It is a movement marked by the 'regulated succession' of strong and weak elements, or of opposite or different conditions".

Crystal (1985: 266-267) defines rhythm as the 'perceived regularity' of prominent units in speech. Yet, he enlarges the definition stating that "these regularities may be stated in terms of patterns of stressed vs. unstressed syllables, syllable length (long vs. short) or pitch (high vs. low), or some combination of these variables". Thereupon, he assumes the importance of prosodic means in creating speech rhythm. Kawaguchi et al. (2006: 203) complements this definition stating that "rhythm is made up by length, loudness, and pitch when applied regularly".

In his later works, Crystal (1987: 59) sticks to the point that "combinations of pitch, loudness and durational characteristics are usually summarized under the heading of rhythm, perceived in terms of 'rhythmic' vs. 'arythmic' speech". This is in accordance with Zellner Keller \& Keller (forthcoming), who likewise claim the crucial role of prosodic means in making up the rhythm of speech, saying that "natural richness and variety of prosodic patterns participate actively in speech rhythm". This thought is 
supported by Brown \& Weishaar (2010:14), who believe that rhythm in speech is regarded as a "property of the inherent prosody of the language".

Roach (1991: 120), in his turn, generalizes this term stating that the notion of rhythm involves some noticeable event happening at regular intervals of time. So, one can see that in phoneticians' views the traditional definition of speech rhythm is "recurrence of stressed syllables at more or less equal intervals of time in a speech continuum" (Vrabel 2009: 102).

The English language has a tendency to the so called alternating rhythm, when stressed syllables occur at approximately regular intervals (Adams 1979: 109). Notwithstanding, these syllables are not isochronous. Calling speech segments isochronous, I mean just the tendency to equal the length of these speech segments since their exact length is considered to be a pseudo statement (Adams 1979: 45). This could be explained by the fact that speech isochrony exists only at the level of perception and therefore gives grounds to call it subjective or perceptual inasmuch as rhythm is always in the mind of the listener (Handel 1989). The available results of experimental studies (Lehiste 1977) reveal that the length of a sound, which is less than $30 \mathrm{~ms}$, is generally not perceived by the human ear. At the same time, the length of any speech segment should reach at least $100 \mathrm{~ms}$ for listeners to perceive it.

Recent experimental results of investigations concerning the multifaceted nature of rhythm of voiced poetic texts (Attridge 1995; Nell 1993; Suppes 2009) still raise a number of theoretically as well as practically oriented questions. Although Vrabel (2009) outlined some basic peculiarities of poetic rhythm, i.e. rhythm in verse, claiming that poems display a tendency to have simple pitch contours with a stepping head, a gently sloping falling nuclear tone, a comparatively slower tempo, and more isochronous rhythmic units. In light of this I must say that the study of the rhythm of American postmodern poetic texts is inherently problematic for many reasons. 
First of all, one must bear in mind that the issue of rhythmicity on the acoustic level in American postmodern poetry was touched upon sporadically (Conte 1991; Cook 2007; Rollison 2003) and does not present any significant results. The reason for such rarity lies in the fact that these texts have come into the focus of research attention recently (Carkic 2010; Conte 1991; Cook 2007; Nunning 1997; Perloff 1998), but seem to be favorable for displays of copyright experimentation, and reflect individual author's artistic consciousness (Малащук-Вишневська 2014). In this regard, it is worth considering the article by Jacoby (2000) who claims that:

The poetry thrown into the digital dither of the World Wide Web is neither discrete nor demure, nor is much of it "good". In today's postmodern era of literature, it does not have to be good. To be poetry, it only need exist... To be poetry in the postmodern age, it doesn't have to be anything or any form in particular; it only has to be. Postmodernism is the age of "literary" indulgence, when anything anyone wants to say - in whatever way they want to say it - is just as much "literature" as anything else.

Such poetic texts are characterized by the creative use of different literary traditions, ignoring causation, ambivalence in terms of their plot, compositional and figurative level, etc. (Бабелюк 2009; Денисова 2002).

For this reason, the ultimate aim of the current research is to accomplish an acoustic analysis of American postmodern poetic texts and not just to define the rhythmicity but to see whether this poetry is rhythmic and to what extent it displays this rhythmicity on an acoustic level.

\subsection{Rhythm-creating factors in American postmodern poetry}

On the basis of the given definitions of speech rhythm it is evident that this speech phenomenon has some kind of alternation in its core. That is why at this stage it is significant to find out the components of speech rhythm on an acoustic level as Jakobson (1979: 131) mentioned: "In investigating the rhythmical structure of a poetic work, one must first of all establish, which linguistic elements are rhythm-creating factors - those language elements, which fulfill a certain rhythmical tendency". 
Seeing that acoustic analysis is known to be an essential part of any phonetic experiment, it is necessary to distinguish acoustic parameters of rhythmicity. Following Kohler (2009: 30), there are at least three parameters of rhythmicity in the analysis of production, perception, and manifestation of the communicative function of speech rhythm. They are "recurring timing patterns of fundamental frequency, syllabic duration, and syllabic energy". In addition, he focuses on their ability to be "produced and perceived as chunking of speech, by creating waxing and waning prominence profiles that occur with some degree of regularity over time".

I will deal with three physical parameters of rhythmic groups, i.e. a unity consisting of one or more words, united by one (sometimes two) stresses, expressing a single semantic whole:

- $\quad$ pitch (or fundamental frequency) - an acoustic correlate of melody, measured in $\mathrm{Hz}$;

- duration - the length of rhythmic groups, intrastressed intervals as well as pauses, measured in ms;

- intensity - an acoustic correlate of volume, a set of amplitude-frequency characteristics and duration of rhythmic units (Калита 2001), measured in dB.

\subsection{Rhythm-enhancing factors in American postmodern poetry}

Since American postmodern poetry is in the focus of the acoustic analysis, my research will revolve around physical parameters. However, besides rhythm-creating factors, one must distinguish in rhythmical structure such elements, which do not create a rhythmical impulse themselves, "but which shade, enrich, and individually colour the rhythm" (Jakobson 1979: 131). Meter, rhyme, and graphic design of the poem belong to such rhythm-enhancing factors in American postmodern poetry.

Meter has always been seen as a guide to vocal performance (Martin 2012: 35) and is known to be a rhythmically regulated alternation of strong and weak syllables in the verse line. Metrics, according to Brown \& Weishaar (2010: 112), was developed as 
tools of statistical measurement of said durational variability in speech. Metrical theory has reduced time to nothing more than linear precedence of discrete grid columns, claiming that the serial order of relatively strong and weak syllables is the only thing that matters in rhythm (Arvaniti 2012). What is more, the presence of a metric organization distinguishes poetry from prose.

Along with meter, rhyme is considered to be a powerful phonetic means of enhancing speech rhythm. This is owing to the fact that in poetic speech rhyme evokes a feeling of harmony and semantic completeness of certain parts of a poem, thus promoting the perception of rhythmic lines and stanzas.

The analysis of graphic design of the investigated material suggests that the graphic presentation of every poetic text adds to its rhythmic layout. Referring to Esser (2011: 99), I must confirm that the graphic presentation in lines and stanzas of traditional poetic texts "is meant as a hint" of how a poem should be phonically presented. Thus, studying the rhythm it is essential to take into account the graphic design of the poem. This could be explained by the statement about the presence of so-called visual rhythm (Lilja, s.a.). While reading a poetic text, this visual rhythm inevitably affects the rhythm on an acoustic level.

That is why I can assume that poetic rhythm will be more evident and regular in those poems, which have an alternation of strong and weak syllables, rhyme and which have a traditional graphic layout of stanzas. However, American postmodern poetry is to a great extent devoid of such rhythm-enhancing factors.

\section{Material and methods}

500 American postmodern poems of the XX-XXI century voiced by their authors American poets, such as M. Levine, H. Nemerov, D.A. Powell, J. Spahr, K. Volkman, $\mathrm{K}$. Young, etc. served as material for the research. The total duration of the recordings of the poetic texts is 9 hours 14 minutes. 
The research was conducted on the basis of a stepwise and coherent methodology, which breaks down the phonetic experiment into a sequence of logical steps, thus making the research clear. The complex methodology of experimental phonetic research was developed on the basis of existing programs, presented and proven in a number of scientific papers (Калита 2001; Alexiyevets 2017; Musiienko 2017).

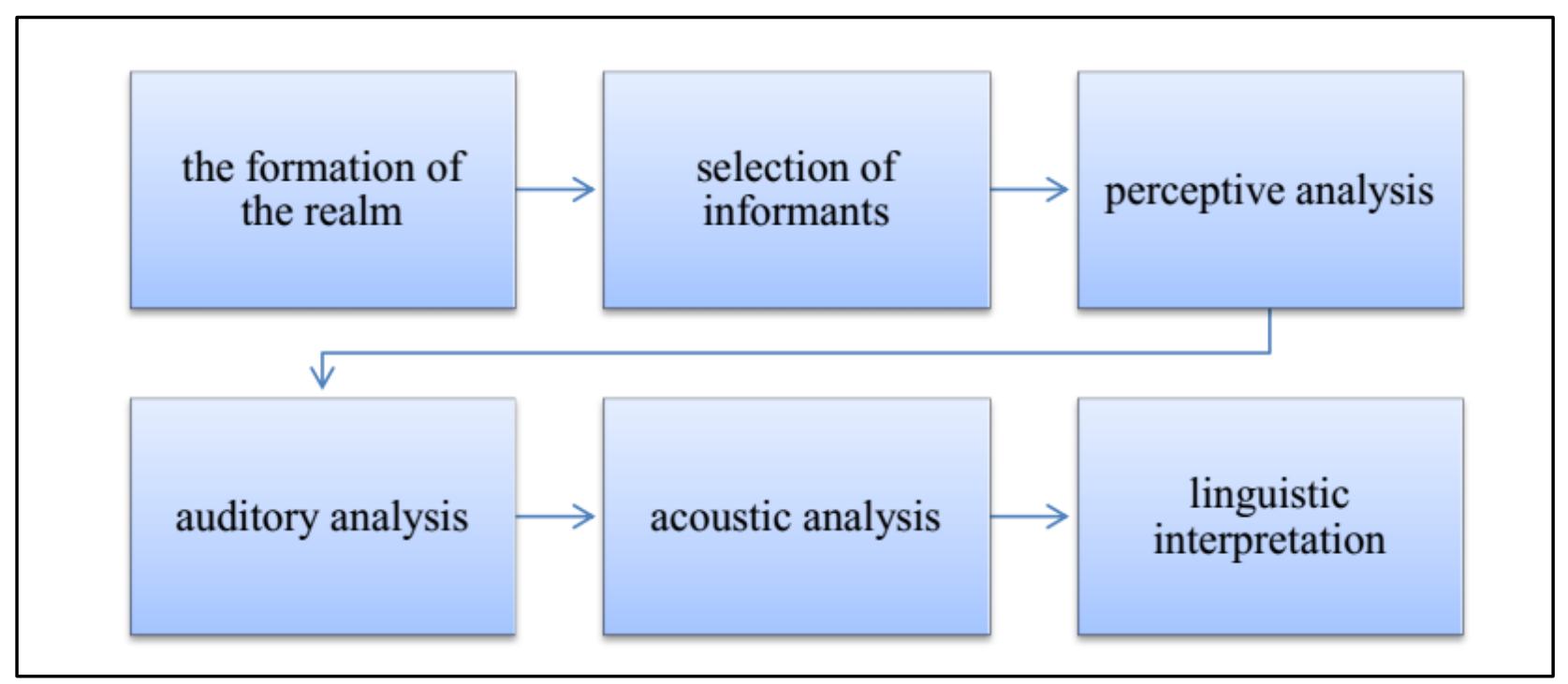

Figure 1. The stages of the phonetic experiment

The program included six successive stages (Fig. 1), namely the formation of the realm of the experimental material, the selection of informants, the perceptive analysis (done by auditors-informants), the auditory analysis (done by auditors - professional phoneticians), the acoustic analysis, and linguistic interpretation of the results. The acoustic analysis was carried out using the computer programs PRAAT, Sound Forge, MP3 Cutter, Speech Analyzer, and Audacity 1.3. Beta (Unicode). First, the voiced poetic texts were cut out from Internet radio broadcasts and authored poetry evenings using the MP3Cutter program. Then the selected material was converted into separate *.wav audio files using the Audacity 1.3 program. It should be taken into consideration that the inclusion of the listener (auditors-informants) as a central authority in the analysis of speech rhythm is crucial since it raises the question of its powerful communicative function. Moreover, it has been claimed since antiquity that rhythm in 
sound generally and in speech in particular, has a guiding function for the listener (Esser 2011).

\subsection{The classification of American postmodern poetic texts}

In the context of the proposed study of the peculiarities of rhythmic organization in poetic speech in the material of American postmodern poetic texts, there is a need to construct a classification of these investigated texts, which will help solve the practical question of the necessary and sufficient scope of material to conduct experimental phonetic research (Калита 2001: 225).

At the same time, Ciplijauskaite (1992) believes that postmodern poetry is generally not subject to any classification. However, a typology of the American postmodern poetic texts from the standpoint of an approach that focuses on revealing the specifics of their rhythmic organization seems to be possible and urgent.

Therefore, since meter is a regulated rhythmic alternation of strong and weak syllables in lines of poetry, the poetic texts can be divided into metric and non-metric (free verse). Consequently, in view of this, the presence of rhyme in the poem enables scholars to divide the spectrum of American postmodern poems into rhymed and unrhymed (Иванюк 2007). In the absence of rhyme, prosodic means play a central role in creating the feeling of rhythm.

Taking into account such rhythm-enhancing factors as graphic design, American postmodern poetic texts can be divided into conventional and unconventional (Unconventional Poetry), or experimental (Починок 2015). Conventional poetic texts are typical in their traditional division of the text into commensurate segments (lines, stanzas), while unconventional ones have a wide range of fonts, reject capitalization with different punctuation design, present noticeable indentation, spaces, etc. 
Accordingly, I classify American postmodern poetic texts (Fig. 2) aiming at a better understanding of the rhythmic organization of these texts. The first line includes principles of text classification, while the $2^{\text {nd }}$ and the $3^{\text {rd }}$ lines demonstrate types of texts.

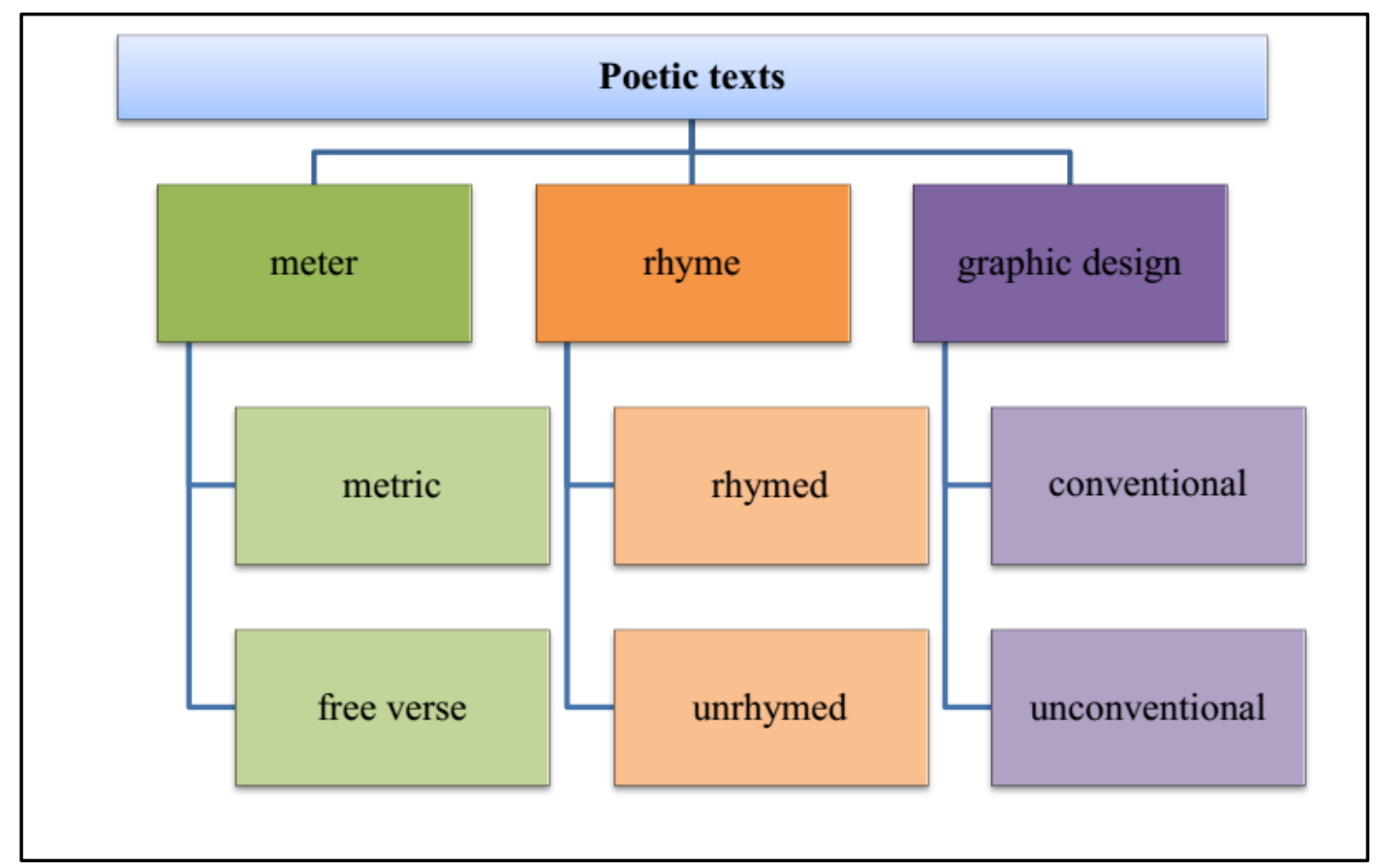

Figure 2. Principles of American postmodern poetic texts classification and their variety (types)

\section{Case study}

\subsection{The results of the auditory analysis}

The results of this survey were obtained by completing a specially designed questionnaire by 5 male and female native speakers of English.

The analysis of American postmodern poems showed that $99 \%$ of poems written by American poets after 1950 are non-metric, which means that regulated rhythmicality of alternating strong and weak syllables is not common for them. At the same time, only $1 \%$ of poems are metric. However, the analysis of the material also revealed numerous cases, where certain lines in the verses were arranged metrically, while the rest of the text remained non-metric. I may presume that this was done deliberately by the author. 
Thus, one may conclude that versification is no longer an essential component of American postmodern poetry. While writing and reading their poems, American postmodern poets do not construct a metrical template. However, the tendency towards the episodic metric organization of lines is still quite a characteristic feature of American postmodern poetry.

The auditors-informants, involved in the phonetic experiment, established the dominance of unrhymed poems (97\%) to rhymed ones (3\%). Rhymed poetry is still peculiar to the works of such postmodern poets as A. Hecht, H. Nemerov, K. Ryan, and others. For example, consider the fragment of "The murder of William Remington", written by Howard Nemerov:

It is true, that even in the best-run state

Such things will happen; it is true,

What's done is done. The law, whereby we hate

Our hatred, sees no fire in the flue

But by the smoke, and not for thought alone

It punishes, but for the thing that's done.

The text refers to the death of a famous American economist, William Remington, who was convicted of being a spy for the former Soviet Union. In prison his fellow prisoners attacked William, who died of the inflicted injuries. The auditors-informants stated that rhyme had great weight in creating the rhythm of this voiced poem. It affected the dynamics of its scoring and provided some musicality to the text. However, such texts turned out to be a rarity, mainly because $\mathrm{H}$. Nemerov wrote his poems at the dawn of American postmodernism.

Thus, the low share of rhyme in poetic texts demonstrates the general tendency of American poetry to rhyme levelling, which is seen as one of the leading factors of rhythmic organization in poetic speech. 
The analyzed poetic texts also vary in terms of their graphic design. It has been established that $69 \%$ of the studied texts are conventional. They are characterized by their respect for traditions in poetry, as reflected in their division into comparable and commensurate pieces. They are thought "to help readers decode the printed text and are medium-dependent metalingual comments indicating chunks of meaning, grammatical structures or possible tone unit boundaries for oral presentation" (Esser 2011: 99). Let me take, for instance, a fragment of a poetic text by A. Sexton, which is called "The expatriates":

My dear, it was a moment

to clutch at for a moment

so that you may believe in it

and believing is the act of love, I think,

even in the telling, wherever it went.

In the false New England forest

where the misplanted Norwegian trees

refused to root, their thick synthetic

roots barging out of the dirt to work on the air,

we held hands and walked on our knees.

Actually, there was no one there.

The auditors indicated that such a graphical presentation of the text, namely relatively uniform lines arranged in columns, contributed to the actualization of visual rhythm that has affected the acoustic rhythm.

However, the range of investigated material also contains numerous poetic texts, which are characterized by a specific experimental graphic design, which is typical of postmodern literature. Thus, the auditors have found a number of American postmodern poetic texts with font diversity, rejection of capitalization or deliberate capitalization of certain fragments of text, quotes, italics, with different punctuation 
design, with noticeable indentation, spaces, and so on. The total share of such poetic texts is $33 \%$.

Let us consider, for instance, a fragment of the poetic text by E. Phillips "Saul Bass redesigns the first man":

I want to make beautiful things, even if nobody cares.

To make, you first have

to create materials. Re: MAN, we know

the rib removed. But, before-?

Forget ash to ash, dust

$\& c$.

Stick a floating rib (i.e. thoracic

11-12, y'know - "Edenic") in a glass

of water with the promise

it'll grow

roots like leek or fur

According to the statements of the respondents, such graphic elements in large quantities lead to the loss of the logical connection of speech perception and complicate the listener's understanding of the voiced poetic text in the context of its prosodic and rhythmic organization as well.

Especially revealing in terms of graphic design are the works of D. Kearney, who, in his own words, wrote in the style of "performative typography" explaining that he "wanted to take what I knew about poetics and, say, graphic design and try to figure out the dynamics of certain poetic devices". A vivid example of this "performative typography" is the poem "Afrofuturism" (Fig. 3). (Poetry foundation, s.a.). 


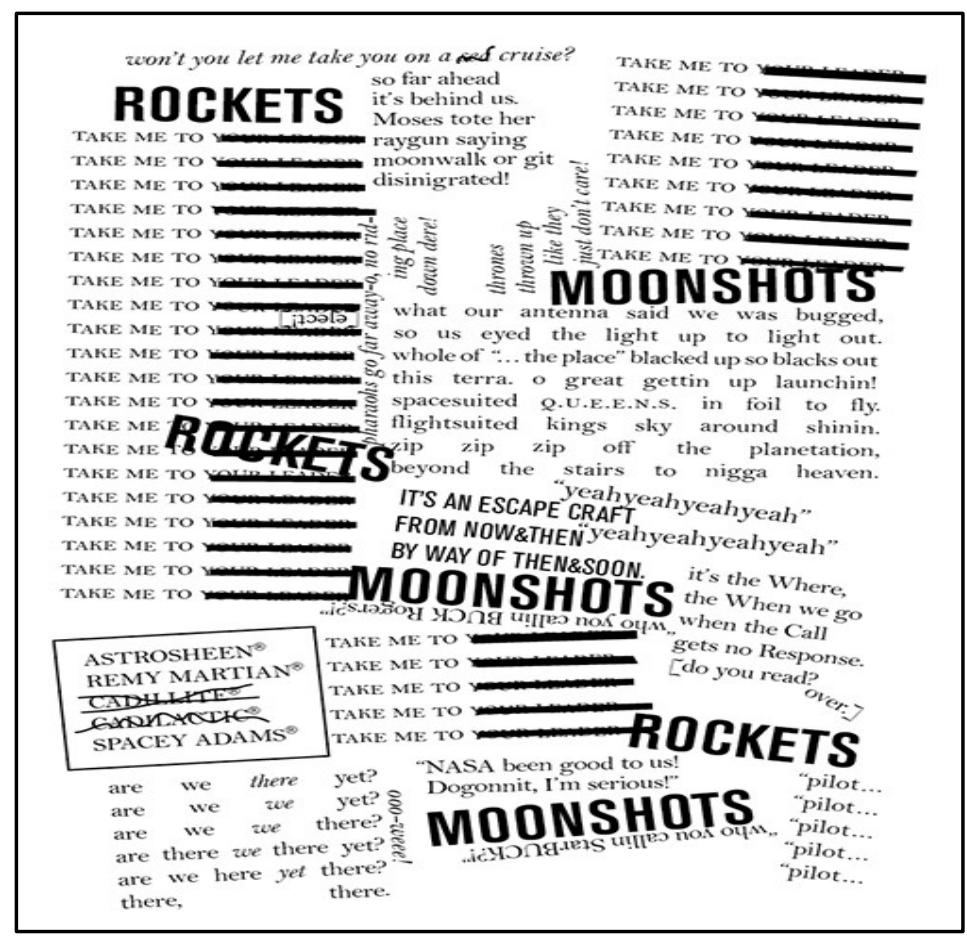

Figure 3. "Afrofuturism" by D. Kearney

The following poetic text "Fathers of the year" (Fig. 4) by the same poet at first sight looks chaotic. The reader has the impression that he/she can get lost in the chaotic flow of the author's thoughts (Бабелюк 2009: 170). This is due to the fact that the graphic form of contemporary American postmodern poetic texts is designed not only to reflect the structure of the work, but, first of all, to set the reader to the emotionality and expressiveness of the message (Малащук-Вишневська 2014: 79).

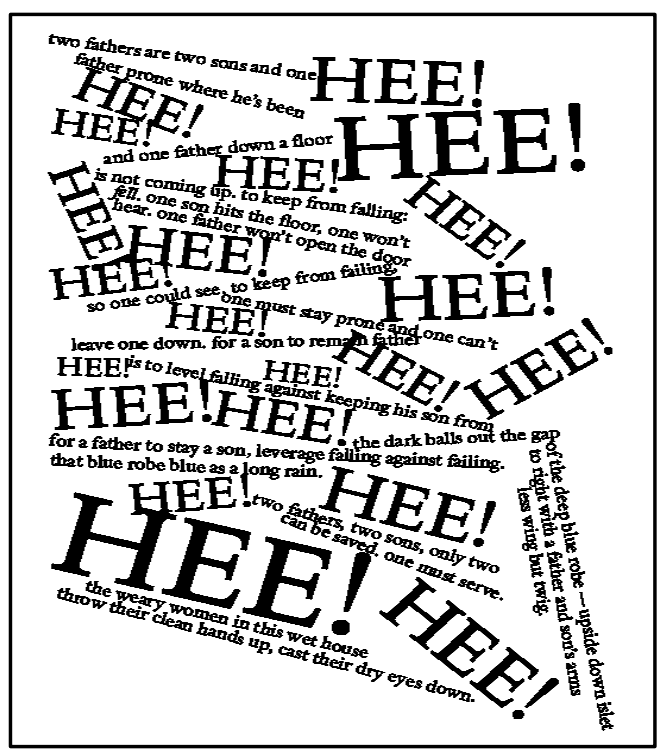

Figure 4. "Fathers of the year" by D. Kearney 
Thus, the above reasoning suggests that the destruction of traditional forms of poetry and modern experimentation over the poetic form became possible apparently due to the visual perception of the image, or the so-called visual rhythm (Lilja, s.a.).

As a way of encoding information, this organization of the text has its advantages as the information is perceived better since it involves both visual and auditory analyzers (Бабелюк 2009: 85). Therefore, it can be stated that modern American postmodern poetic speech is intermedial, i.e. multimodal and requires a multiplicity of semiotic codes that include verbal, visual and auditory codes involved in the communication (Воробйова 2012: 5).

This polycoding is probably caused by multiculturedness in national, social, and general cultural plans (Бабелюк 2009: 50) as well as the cultural, linguistic, and stylistic multilingualism of postmodernism. However, such an organization, for its part, may result in the loss of logical connection, specific difusion, particularly when the poetic text is being voiced, and will require additional effort of thinking during its phonologic coding.

Therefore, I must assume that since American postmodern poetic texts are vers libres and are mainly unconventional in terms of their graphic presentation, such prosodic means as pitch, duration of syllables and intensity form the feeling of rhythm.

\subsection{The results of the acoustic analysis}

\subsubsection{The tonal characteristics}

One of the objectives of the research of the tonal features of postmodern American poetic speech at this stage of our study was to describe the tone that auditorsphoneticians defined as low falling tone, high falling tone, low rising tone, and high rising tone. The tonal characteristics of the voiced poetic texts indicate the prevalence of a falling tone $(\backslash)$, which often alternates with a rising melodic contour $(/)$, which can 
be illustrated using examples taken from the poetic work of the American poet $\mathrm{H}$. Nemerov "The goose fish":

On the long / shore, lit by the / moon

To show them properly a $\backslash$ lone,

Two lovers suddenly em / braced

So that their shadows were as $\mid$ one.

Such features of alternating melodic contours are generally typical of rhymed poetic texts. As one can see from the example, the first line consists of two syntagmas, On the long shore and lit by the moon, which have a rising tone. The second line of the verse, which correlates with the syntagma, to show them properly alone, has a descending tone. The third syntagma, two lovers suddenly embraced, has a rising tone, while the fourth syntagma, so that their shadows were as one, again has a falling tone. In unrhymed free verses, the falling tone $(\backslash)$ alternates with the level one $(\rightarrow)$. Consider this fragment from B. Gest's "The blue stairs":

The code $\rightarrow$

consists in $\mid$ noticing

the particular shade $\rightarrow$

of the I staircase

The following fragment of the poetic text "Famous negro athletes" by Kevin Young demonstrates recurrency of certain melodic contours that enliven the poetic speech and contribute to the avoidance of a monotonous rhythm. Futhermore, the presence of such stylistic means as enjambment affects the melodic layout of lines, i.e. in this case the medium-independent clause structure does not require or even suppresses a tone unit boundary (Esser 2011: 99). This results in the smooth melodic contour of the poetry realization. 
/ B a'nomaly $\rightarrow$

a / nomaly he 'be $\rightarrow-$

'caught be | tween

a / hock

and a 'hard $\backslash$ race-

From the 'peak $\rightarrow$

You can 'almost'see $\rightarrow$

the 'far

I Side of the 'river $\rightarrow$

'Lights 'stretch $\rightarrow$

'Out su'burban $\rightarrow$

I satisfied

/ Black is /'this

'season in

It / goes

With | everythin-

/ They know'not $\rightarrow$

who he / is be'cause $\rightarrow$

he is 'not'like

what 'ever they 'know $\rightarrow$ 
The tonal characteristics of free verses are different from those of rhymed poetic texts. Consider the fragment from the poetic text "The goose fish", written and voiced by $\mathrm{H}$. Nemerov.

Until they 'saw, 'there under'foot //

Untill the world had found them out //

The goose fish turning up though dead /

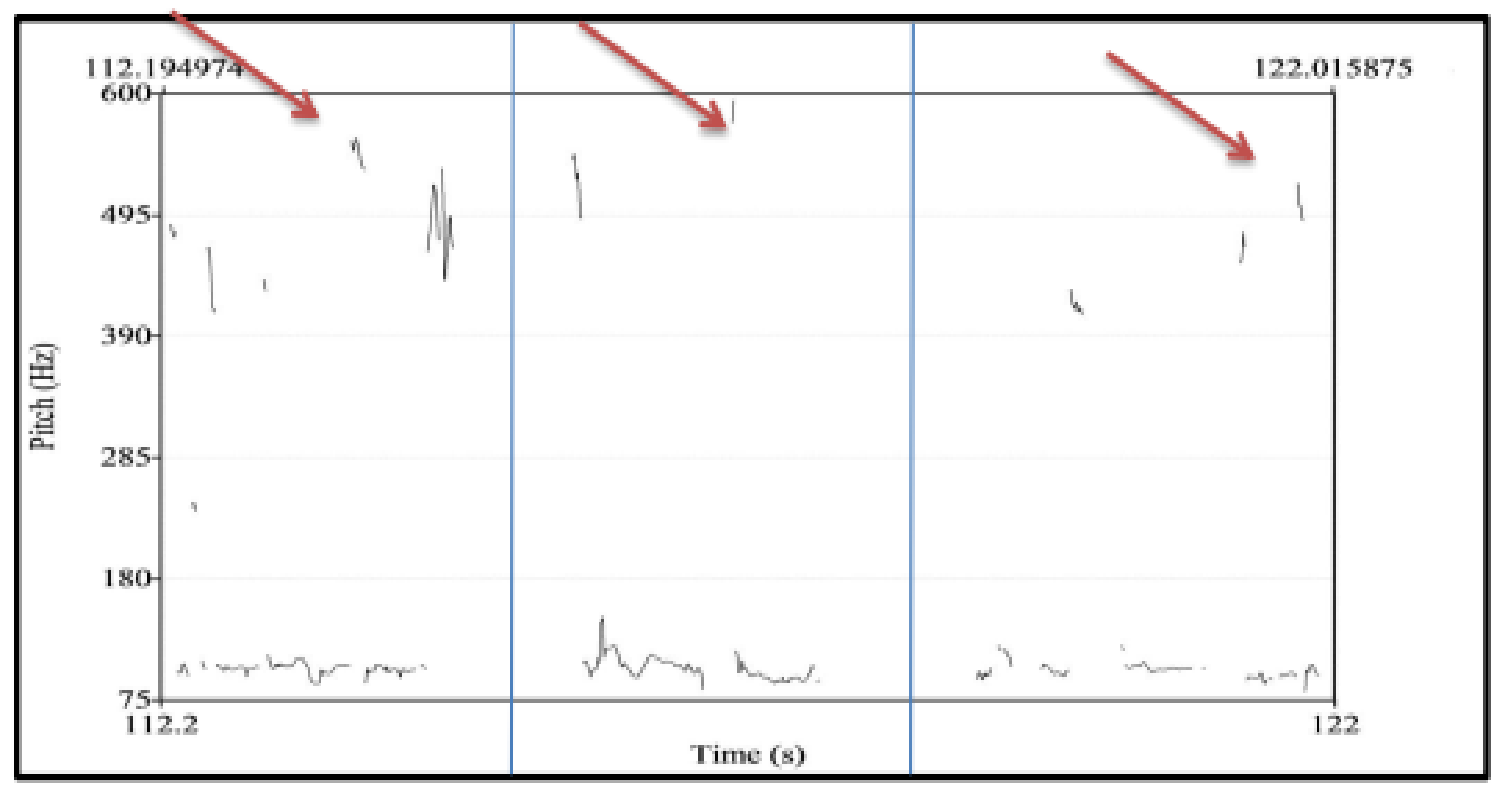

Figure 5. The frequency in the utterance Until they 'saw, 'there under'foot // Untill the world had found them out // The goose fish turning up though dead by H. Nemerov "The goose fish"

Figure 5 demonstrates that while being rhymed, this poetic text has repeated and quite significant increases of frequency (up to $600 \mathrm{~Hz}$ ) in each line of the stanza.

\subsubsection{The intensity characteristics}

Due to computer speech analyzers, I fixed the intensity of acoustic oscillations, in particular, I was able to set the maximum and minimum peak of this speech parameter. In addition, on the basis of the obtained measurements, it was possible to determine the average intensity value and to characterize its dynamics. The study of intonograms on the energetic parameters of poetic speech showed that the data of the acoustic analysis in general coincided with the data, obtained during the auditory analysis. 
For example, the voiced fragment of "Fathers of the year" by D. Kearney is characterized by a stable increased intensity on the exclamations (Fig. 6) and a low rate of intensity on the rest of the syntagmas. This creates a relatively large range of intensity within the analyzed syntagmas.

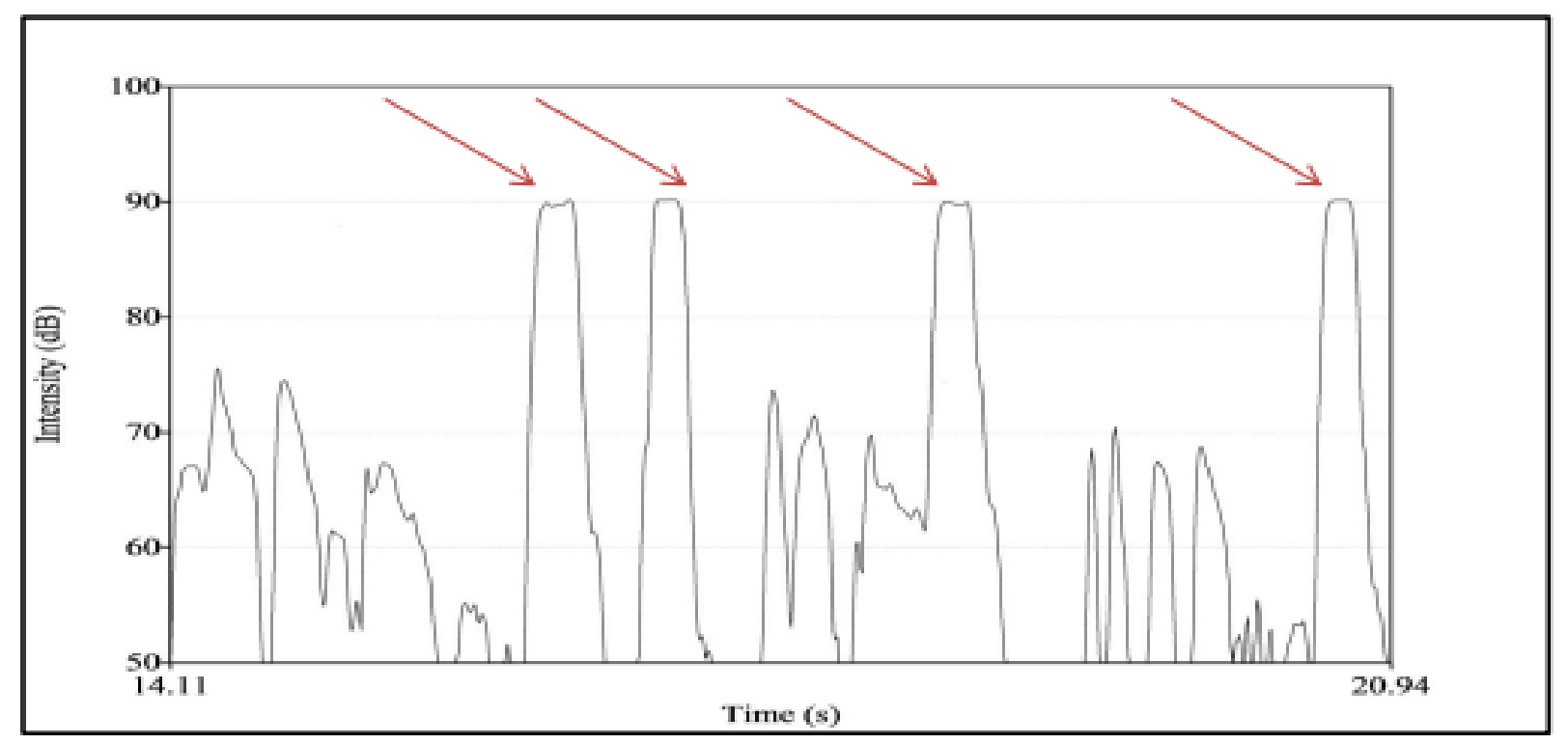

Figure 6. The intensity indicators in And one father down the floor Hee! Hee! Is not coming up Hee! To keep from falling Hee "Fathers of the year" by D. Kearney

The presence of the onomatopoetic exclamation "Hee!", which can be viewed as an emotionally expressive means of communication and serves as an indicator for laughter, has specific intensity data (Fig. 6). (The arrows point to the maximum intensity figures recorded on all the exclamations of "Hee!"). It should be noted that all the exclamations "Hee!" in the author's voice recording are characterized by increased intensity rates in comparison to the rest of syntagmas, resulting in a maximum intensity, which rises to $90.1 \mathrm{~dB}$. This presents a sharp contrast even with the maximum of intensity indicators of the remaining syntagmas.

That is why, such a location of the intensity peaks in syntagmas, as well as the systematic appearance of such exclamations with approximately the same intensity rate (90-90.2 dB), makes them prominent, thus forming a peculiar aural image of the American postmodern poetic text. 
The data from acoustic analysis shows that regular rhythm can be created due to the constant placement of intensity maxima in the author's manifestation of the poetic text "LA Oddysey" by C. Sigo. In this work, the American poet Cedar Sigo travels around the Pacific Ocean and shows us his unique version of Los Angeles as he sees it. The text is postmodern because it is full of intertextual elements: the films of Robert Blake, family books, dinosaurs of the land, sea and air, etc.

In the analyzed fragment the intensity maxima is located on the first stressed syllable of the syntagma: (accented syllables of words, which have the highest rate of intensity are in bold, above them the indicator of intensity in $\mathrm{dB}$ ).

$67,5 \quad 73 \quad 73,5$

Hiding out. || Nick is too kind. || Two black and slowly moving marbles against

$$
\begin{array}{lll}
71,2 & 70,2 & 70,5
\end{array}
$$

flesh || Sara, || a model of containment. || Brian is luminous \| (all eyes)

Then the intensity peaks shift and are located on the second stressed syllable of the syntagma:

$$
67,5
$$

Twin fires beyond the pit || that only crackles green

Then again the intensity maxima are steadily located on the first stressed syllable of the syntagma:

72,7

67,3

68,7

My black hobo sack abandoned \|And thought a bomb. || I was seamlessly high 69,1 66,2 on my air heels || and driven away to where $\|$ the camera could not follow. 
Thus, the alternation of intensity peaks location creates a steady rhythmic pattern of the author's reading, resulting in creating a pleasant melodic rhythm. The intensity proves to be a rhythm-creating parameter in voiced American postmodern poetry.

\subsubsection{The duration characteristics}

The body of data on the duration of rhythmic groups demonstrates that these rhythm units vary to a great extent in voiced American postmodern poetic texts. The range of their duration is wide and varies from 106 to $1563 \mathrm{~ms}$, where the shortest recorded rhythm group lasts only $106 \mathrm{~ms}$, and the longest one is realized with a duration of 1563 ms.

The results of acoustic analysis provide evidence for the fact that the poets, while reading their works, manipulate the duration of rhythmic groups of the same type and which have the same amount of syllables for the embodiment of a certain image of a poem or the whole system of images in the text. Furthermore, they do it in order to achieve a certain pragmatic effect.

Consider the examples (Fig. 7), in which some one-syllable rhythmic groups are pronounced much longer than those with the same composition. Here, the emphatic longitude is clearly manifested by the increase in the duration of one or more sounds, or as a result of the dismemberment of the stages of sound creation - the excursion and the endurance (one-syllable rhythmic groups are highlighted in bold; the duration in milliseconds is placed under appropriate rhythmic groups):

$\begin{array}{cccc}\text { Otherwise } \mid & \text { drink } \mid & \text { water } \mid \quad \text { lie } \mid & \text { to yourself } \mid \\ 272 & 863 & \\ \text { now } \mid & \text { must } \mid & \text { begin again } \mid \text { it must } \mid \text { be new } \mid \text { time } \mid \\ 812 & 258 & & \end{array}$

Figure 7. The duration of one-syllable rhythmic groups in

"If you are over staying woke" by M. Parker 
This duration is quite contrasting. Such actions of the poet are motivated by the desire to reach the emphasis - the expression of an important part of the speech in the semantic aspect. Therefore, it becomes obvious for the listener that the call for revolutionary changes is realized by accentuating the word now, where the new time should begin now.

It is interesting to state that syntagmas, which have a different number of syllables, can form no less striking a rhythmic pattern thanks to their variation of duration, which is rich in contrast as well. The following fragment of a poetic text by H. Nemerov "The goose fish" demonstrates how the poet manipulates the duration of syntagmas, where the syntagmas, which consist of 8 syllables, are spoken with different duration (the number of syllables in syntagmas are in brackets and the acoustic indicators of syntagmas mark syntagmatic duration in milliseconds in bold).

Then $\|$ (1) as if shaken by stage fright $\|$ (7)

684 2339

Beneath the hard moon's bony light $\|$ (8)

2625

They stood together on the sand $\|$ (8)

2101

Embarrassed in each other's sight \| (8)

1934

But still conspiring hand in hand $\|$ (8)

2674

Until they saw there underfoot $\|$ (8)

2555

As though the world had found them out \| (8)

2318

The goose fish turning up though dead \| (8) 
His hugely grinning head $\|$ (6)

1997

There in the china light he lay \|(6)

\section{1}

Most ancient and corrupt and grey \| (8)

\section{3}

The example demonstrates that due to the length of the rhythmic group the poet emphasizes the important images of the poetic text, which in this example is the goose fish, a deep-sea predatory fish, which has a very nasty appearance. In the story of the work two young people spend a romantic time on the beach. Because of their passion, they do not notice that all this time they are under the supervision of the fish, which in this poetic text can be interpreted in two ways: as space (as opposed to human egocentrism) and as death (as opposed to life).

Thus, a person either being in his/her illusions and does not notice the world around them, or death is always present in every minute of our lives, even in fairly intimate moments. The appearance of the fish "The goose fish turning up though dead" (3100 $\mathrm{ms}$ ) and its description "Most ancient and corrupt and grey" (3093 ms) in the author's reading is marked by a longer duration of the syntagma as evidenced on the acoustic level.

Consider, for example, unrhymed poetic text "Whiteread walk" by Joshua Clover. Logically, its syntactic organization requires some breaks, because the poetic text is quite long in duration - it lasts $35 \mathrm{~ms}$. Moreover, the poem is apunctual where the presence of pauses is largely expected, but the absence of any punctuation marks within the fragment confuses the reader to a great extent.

Monumental the lacunae between illbiquitous promenaders down to the Square past the Open 24 Hours as social forms of grieving we are prohibited this is the remix the 
new glitch has been recalled melancholy of luscious Pictober the fall of the phenomenon into the iris back with another one of those Return of the Flaneur as hardcore Autumnophage echolocation always places you in a different country the cure is beats per minute bad year in Brooklyn Bombs Over Baghdad the negative needs no introduction and/or here we go!

("Whiteread walk" J. Clover)

The analyzed poetic text portrays an urban mode of living and the life of a city resident, and also affects the US foreign policy. The text generally depicts a poet's life that is responsive to technological progress and the pressure of information arena. In the text, French poet Charles Baudelaire, a Paris wretch of the nineteenth century, is walking round the town and comments on its modern urban space.

While analyzing the recorded text, the auditors, involved in the phonetic experiment, identified only four pauses (Fig. 8), which they claimed were short and coincided with breathing pauses. The information in the poetic text, which is immediately given by the poet, doesn't seem to have been designed for reconsideration but for a quick response (Бабелюк 2009: 241). It becomes apparent that the listener relates this fast paced text with a fast pace of life, devoid of stable rhythm, and pauses are meant not to have a rest or reflect upon something, but simply to breathe in or out.

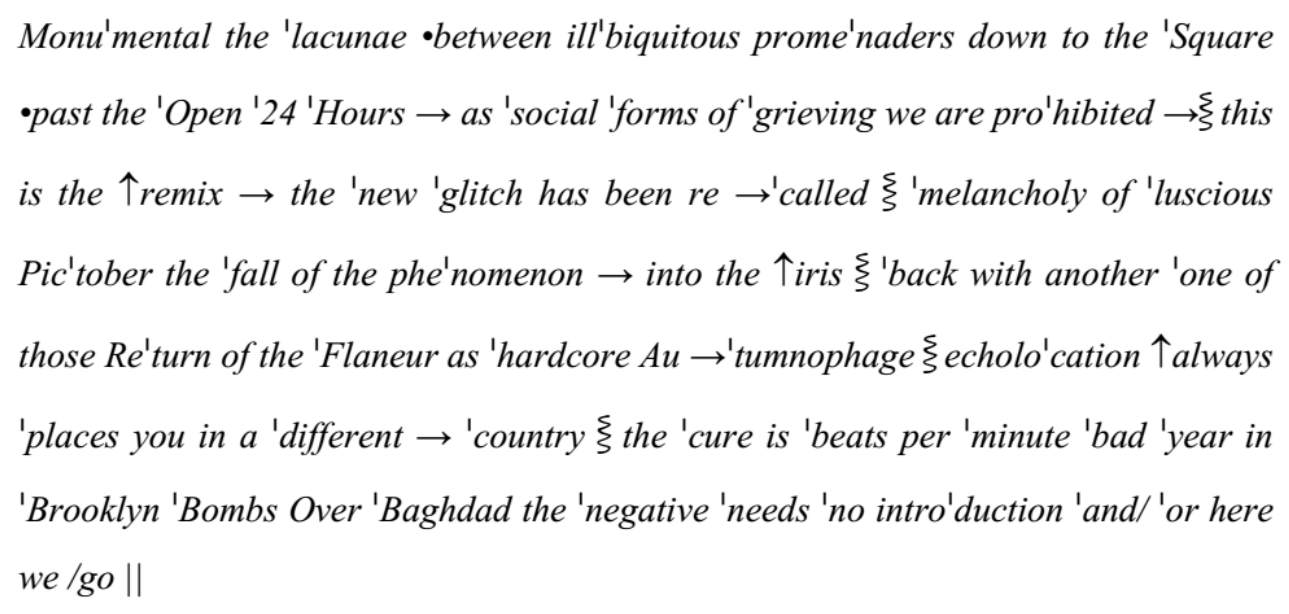

Figure 8 . The phonetically marked poetic text "Whiteread walk" by J. Clover 
On the one hand, a flaneur, promenade means an idle man-about-town (MWOD, s.a.), i.e. a person who walks or drives slowly, enjoying life and exploring the city. On the other hand, the pace of modern human existence requires speed. Moreover, the poetic text is devoid of punctuation marks. This, in general, creates the effect of a stream of consciousness, which is overloaded with information.

Additionally, the lack of correlation between pausation and syntagmatic division obviously has some pragmatic implications. The poetic text is pronounced without a single pause, so it seems that the poet doesn't aim at influencing the listener. As a result of auditory and acoustic analyses, it has been revealed that the breaks turned out to be physiological pauses. The important information (Brooklyn Bombs Over Baghdad) is graphically marked in capital letters, but in the implementation of the text the information is perceived by the listener as background since it is inseparable even with the help of the shortest pause.

\subsubsection{The duration of intrastressed intervals}

The study of the duration of intrastressed intervals is an integral step of any experimental phonetic research of speech rhythm, taking into account that English is one of the stress-timed languages. This means the presence of periodicity of pulses (or stresses). This step of the experiment presupposed the measurement and acoustic analysis of 500 intrastressed intervals taken in milliseconds.

The available results indicate that the range of unstressed intervals varies from 80 to $1154 \mathrm{~ms}$. Short intrastressed intervals are peculiar for the poetic texts of American postmodernism because in these texts authors (i.e. poets) tend to accentuate every word, even those, which traditionally shouldn't be stressed, e.g., conjunctions, prepositions, pronouns, etc. Moreover, the use of one-syllable words is also seen as a reason for shortening intrastressed intervals. Consider the example from "Darling can you kill me" by D.A. Powell (Fig. 9): 


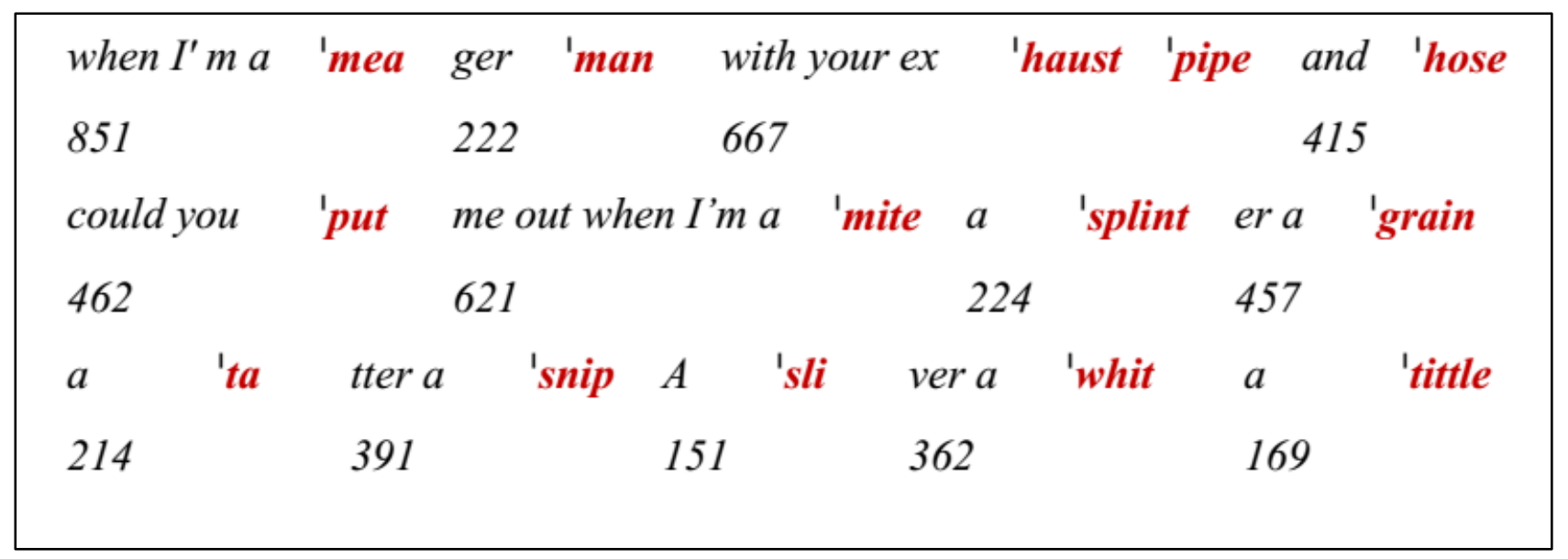

Figure 9. The duration of intrastressed intervals of the fragment from "Darling can you kill me" by D.A. Powell

The rhythm of the text on the acoustic level is formed by relatively isochronous intrastressed intervals that alternate with other intrastressed intervals, or follow one another.

In the above mentioned example, the duration of the intrastressed intervals suggests that they are isochronous fragments because their duration difference is less than $20 \%$, so these pieces of speech are perceived by the human ear as isochronous (CouperKuhlen 1993: 17). As one can see in the example, the intrastressed fragments with a duration of 214-222 ms appear in such a way that they alternate with intrastressed intervals whose duration range is $415-462 \mathrm{~ms}$. At the same time, there are some intrastressed isochronous intervals (151-169 ms duration), which alternate with intervals of 362-391 ms and 621-667 ms respectively.

Furthermore, the rhythm of speech is also provided by the sequence of relatively isochronous intrastressed intervals with a duration of 404-452 ms (Fig. 10):

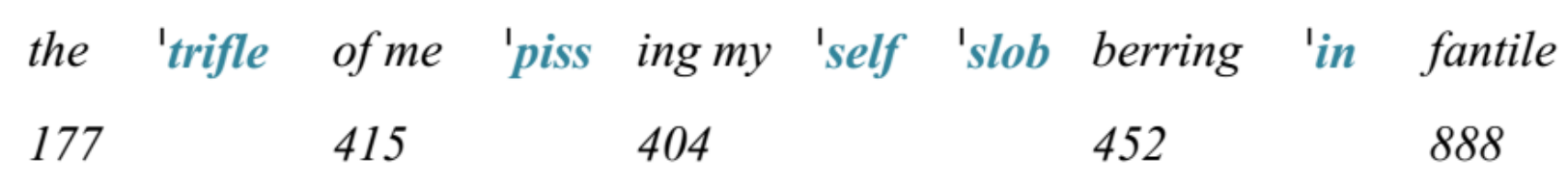

Figure 10. The duration of intrastressed intervals of the fragment from "Darling can you kill me" by D.A. Powell 
Moreover, such isochronous fragments contribute to the dynamism of the text and the impression of a rapid rhythm.

However, the emergence of intrastressed intervals, that differ significantly in their duration, indicates the arrythmicity of speech fragments. For example, J. Clover's reading of "Famous negro athletes" clearly traces the arythmicity of intrastressed intervals, particularly in those text fragments, which are considered by the author as key (Fig. 11). In the utterance because he is not like whatever they know the reason for the rejection of a young African American by American society is explained. The theme of racial discrimination is de facto a core theme in this poem. The duration of intrastressed intervals in this utterance is not distinguished by its regular alternation:

\begin{tabular}{|c|c|c|c|c|c|c|c|}
\hline be & 'cause & he is not & 'like & what & 'ev & er they & 'know \\
\hline 203 & & 873 & & 635 & & 562 & \\
\hline
\end{tabular}

Figure 11. The duration of intrastressed intervals of the fragment from "Famous negro athletes" by J. Clover

That is why it can be argued that arrhythmic fragments of speech are the source of the effect of deceived expectancy and contribute to additional accentuation and emphasis of those fragments of speech, which are key to the decoding of the author's intention.

\section{Conclusions and perspectives}

I have arrived at some major conclusions. First and foremost, American postmodern poetis texts are mainly vers libres and consequently present more opportunities for alternative reading. The rhythm-creating factors of this poetry include such physical parameters as fundamental frequency, duration, and intensity of rhythmic groups. Along with that, there are some rhythm-enhancing factors, which heighten the feeling of rhythm on the perceptive level more than on the acoustic level. They include meter, rhyme, and graphic design. On the basis of the aforementioned factors I classified the 
material into metered vs. free verses, rhymed vs. unrhymed and conventional vs. unconventional poetic texts.

My study revealed that meter and rhyme, which have tradidionally been seen as significant components of poetic rhythm are of little importance when it comes to American postmodern poetic texts.

These conclusions follow from a comprehensive methodology of phonetic research of the rhythmic organization of American postmodern poetic texts. It envisaged five consecutive stages: the formation of the body of the experimental material, the selection of informants, the perceptual analysis of the acoustic analysis and linguistic interpretation.

The acoustic analysis of the three physical paremeters - fundamental frequency, duration, and intensity - proves that they are rhythm-creating factors in American postmodern poetry due to their periodic fluctuations. The research also revealed that poetic texts of American postmodernism can be arrhythmic. In this case, they create the effect of defeated expectancy, emphasizing those speech fragments, which are crucial in the decoding of the author's intention.

These findings have an important implication and present a promising and growing area of study. The detailed study of postmodern poetry in terms of its phonetic presentation is worth considering. Furthermore, it would be of great significance to study the prosodic organization of American postmodern poetry in comparison to poetic texts of other time periods, literature trends, and nationalities.

\section{List of abbreviations}

$\mathrm{Hz}-$ hertz

ms - millisecond(s)

$\mathrm{dB}-\operatorname{decibel}(\mathrm{s})$ 
MWOD - Merriam-Webster online dictionary

Diacritic marks

\begin{tabular}{|c|l|}
\hline The tonic stress marks & \multicolumn{1}{|c|}{ Meaning } \\
\hline m & stressed syllable \\
\hline$\cdot \mathrm{m}$ & partially stressed syllable \\
\hline $\mathrm{m}$ & high falling tone \\
\hline$\uparrow \mathrm{m}$ & rising tone \\
\hline$\rightarrow \mathrm{m}$ & special rise \\
\hline $\mathrm{m}$ & level tone \\
\hline$\xi$ & short pause \\
\hline$\|$ & pause of perception \\
\hline & long pause \\
\hline
\end{tabular}

Figure 12. Diacritic marks used in the paper

\section{References}

Abercrombie, D. (1967). Elements of general phonetics. Edinburgh: Edinburgh University Press.

Adams, C. (1979). English speech rhythm and the foreign learner. The Hague: Mouton.

Alexiyevets, O. (2017). Prosody of the viewpoint in political discourse. In Lege artis. Language yesterday, today, tomorrow. The journal of University of SS Cyril and Methodius in Trnava. Warsaw: De Gruyter Open, 2017, vol. II (1), June 2017, p. 4-41. DOI: 10.1515/lart-2017-0001

Arvaniti, A. (2012). The usefulness of metrics in the quantification of speech rhythm. In Phonetics, 40, p. 351-373.

Attridge, D. (1995). Poetic rhythm. Cambridge: Cambridge University Press.

Babeliuk, O.A. (2009). The principles of postmodern text writing of modern American prose of short form. Drohobych: Vymir. / Babeliuk O.A. Pryntsypy postmodernists'koho tekstotvorennya suchasnoyi amerykans'koyi prozy maloyi formy. 
Drohobych: Vymir. / Бабелюк О.А. Принщипи постмодерністського текстотворення сучасної американської прози малої форми. Дрогобич: Вимір. Brown, S. \& Weishaar, K. (2010). Speech is "heterometric": The changing rhythms of speech. In Proceedings of speech prosody, Chicago, USA, 10-14 May, 2010. Available at: http://speechprosody2010.illinois.edu/papers/100074.pdf

Carkic, M.Ž. (2010). On poetic language. Belgrade: Institute of the Serbian language, Serbian Academy of Sciences and Arts.

Ciplijauskaité, B. (1992). Recent poetry and the essential word. In Studies in $20^{\text {th }}$ century literature, 16(1). Available at: http://dx.doi.org/10.4148/2334-4415.1295

Conte, M.J. (1991). Unending design: The forms of postmodern poetry. Ithaca: Cornell University Press.

Cook, A.S. (2007). Forces in modern and postmodern poetry. New York: Peter Lang Inc., International Academic Publishers.

Couper-Kuhlen, E. (1993). English speech rhythm: Form and function in everyday verbal interaction. Amsterdam: John Benjamins Publishing.

Crystal, D. (1987). Clinical linguistics. London: Edward Arnold.

Denysova, T.N. (2002). Modern American literature: Problems of studying and teaching. Mykolaiv: Mykolaiv Petro Mohyla State University. / Denysova T.N. Suchasna amerykans'ka literatura: Problemy vyvchennya ta vykladannya. Mykolayiv: Vydavnytstvo MDGU imeni Petra Mohyly. / Денисова Т.Н. Сучасна американська література: Проблеми вивчення та викладання. Миколаїв: Видавництво МДГУ ім. Петра Могили.

Dictionary of linguistics and phonetics. (1985). Crystal, D. (ed.). $2^{\text {nd }}$ ed. Oxford: Blackwell.

Esser, J. (2011). Rhythm in speech, prose and verse: A linguistic description. Berlin: Logos Verlag.

Handel, S. (1989). Listening. An introduction to the perception of auditory events. Cambridge: MIT Press.

Harding, D.W. (2010). Words into rhythm: English speech rhythm in verse and prose. Cambridge: Cambridge University Press. 
Ivaniuk, B.P. (2007). Poetic speech. Glossary of terms. Moscow: Flinta: Nauka. I Ivaniuk, B.P. Poeticheskaya rech'. Slovar' terminov. Moskva: Flinta, Nauka. / Иванюк Б.П. Поэтическая речь. Словарь терминов. Москва: Флинта: Наука.

Jacoby, P.R. (2000). Postmodernist poetry: A movement or an indulgence? (A study of Elizabeth Bishop, Sylvia Plath, and Anne Sexton). Available at: https://ru.scribd.com/document/252699847/Postmodernist-Poetry

Jakobson, R. (1979). Selected writings: On verse, its masters and explorers. The Hague: Mouton Publishers.

Kalyta, A.A. (2001). Phonetic means' of sense actualization of the English emotional utterance. Kyiv: Vydavnychyj tsentr KNLU. / Kalita A.A. Fonetychni zasoby aktualizatsiyi emotsijnoho vyslovliuvannya. Kyiv: Vydavnychyi tsentr KNLU. I Калита А.А. Фонетичні засоби актуалізаиії смислу англійського емочійного висловлювання. Київ: Видавничий центр КНЛУ.

Karpichenkova, E.P. (1981). The role of the temporal component in the rhythmic organization of the verse (phonetic research on the material of modern English poetry). Thesis for the Candidate Degree in Philology, Speciality 10.02.04 - Germanic Languages. Moscow: Moscow Moris Torez State Pedagogical Institute of Foreign Languages. / Karpichenkova, E.P. Rol' temporal'nogo komponenta v ritmicheskoj organisatsii stikha (eksperymental'no-foneticheskoye issledovaniye na materiale sovremennoj anglijskoj poezii). Dissertatsiya na soiskanie uchenoj stepeni kandidata filologicheskikh nauk. Moskva: Moskovskij gosudarstvennyj pedagogicheskij institut imeni Morisa Toreza. / Карпиченкова Е.П. Роль темпорального компонента в ритмической организации стиха (экспериментально-фонетическое исследование на материале современной английской поэзии). Диссертация на соискание степени кандидата филологических наук. Москва: Московский государственный педагогический институт иностранных языков им. Мориса Тореза.

Kawaguchi, Y., Fonagy, I. \& Moriguchi, T. (2006). Prosody and syntax: Crosslinguistic perspectives. Tokyo: John Benjamins Publishing. 
Kohler, K.J. (2009). Rhythm in speech and language: A new research paradigm. In Phonetica, 66 (1-2), p. 29-45. DOI: 10.1159/000208929

Lehiste, I. (1977). Isochrony reconsidered. In Journal of phonetics, vol. 5, p. 253-263. Lilja, E. Towards a theory of aesthetic rhythm. Available at: http://lir.gu.se/digitalAssets/1269/1269291 TowardsTheoryRhythm.pdf

Malashchuk-Vyshnevs'ka, N.V. (2014). The poetics of nonsense in verse texts in American modernism and postmodernism: Stylistic and cognitive aspects. Thesis for the Candidate Degree in Philology, Speciality 10.02.04 - Germanic Languages. Kyiv: Kyiv National Linguistic University. / Malashchuk-Vyshnevs'ka N.V. Poetyka nonsensu $v$ amerykans'kykh virshovanykh tekstakh modernizmu i postmodernizmu: Stylistychnyj ta kohnityvnyj aspekty. Dysertatsiya na zdobuttya vchenoho stupenia kandydata filolohichnykh nauk. Kyiv: Kyivs'kyj natsional'nyj linhvistychnyj universytet. / Малащук-Вишневська Н.В. Поетика нонсенсу в американських віршованих текстах модернізму $i$ постмодернізму: Стилістичний та когнітивний аспекти / Дис. ... кандидата філологічних наук / Київ: Київський національний лінгвістичний університет. 10.02.04 - германські мови..

Martin, M. (2012). The rise and fall of meter: Poetry and English national culture, 1860-1930. Princeton, NJ: Princeton University Press.

May, J.M. \& Wisse, J. (2001). Cicero. On the ideal orator. Oxford: Oxford University Press.

Merriam-Webster online dictionary. Available at: https://www.merriam-webster.com/ Musiienko, Yu. (2017). Linguo-cognitive and pragmatic features of the prosodic organisation of English parables. In Lege artis. Language yesterday, today, tomorrow. The journal of University of SS Cyril and Methodius in Trnava. Warsaw: De Gruyter Open, 2017, vol. II (1), June 2017, p. 210-261. DOI: 10.1515/lart-2017-0006

Nell, S.D. (1993). Toward a theory of rhythm in French poetry: Computer assisted recognition of rhythmic groups in traditional isometrical alexandrines. Available at: http://link.springer.com/article/10.1007/BF01830070

Nemerov, H. (1993). A Howard Nemerov reader. Washington: University of Missouri Press. 
Nespor, M. (1990). On the rhythm parameter in phonology. In Logical issues in language acquisition. Roca, I. (ed.). Foris, Dordrecht, p. 157-175.

Nunning A. (1997). Crossing borders and blurring genres: Towards a typology and poetics of postmodernist historical fiction in England since the 1960s. In European journal of English studies. London: Taylor \& Francis, vol. 1, p. 217-238.

O'Connor, J.D. (1977). Phonetics. Wallingford, United Kingdom: Penguin Books Ltd. Oxford English dictionary. (1989). $2^{\text {nd }}$ ed. Oxford: Oxford University Press. Available at http://www.oed.com

Perloff, M. (1998). After free verse: The new non-linear poetries. Available at: http://epc.buffalo.edu/authors/perloff/free.html

Pochynok, Yu.M. (2015). Ukrainian experimental poetry of the late XX-early XXI century: Text, context, intertext. Thesis for the Candidate Degree in Philology, Specialty 10.02.06 - Theory of Literature. Lviv: Lviv Ivan Franko National University. / Pochynok Yu.M. Ukrayins'ka eksperymental'na poeziya kintsya XX-pochatku XXI stolittia: Tekst, kontekst, intertekst. Dysertatsiya na zdobuttia vchenoho stupenia kandydata filolohichykh nauk. L'viv: L'vivs'kyj natsional'nyj universytet imeni Ivana Franka. / Починок Ю.М. Украӥнська експериментальна поезія кіния XX-початку XXI століття: Текст, контекст, інтертекст / Дис. ... канд. філол. наук / Львів: Львівський національний університет імені Івана Франка. 10.01.06 - теорія літератури.

Poetry foundation. Available at: http://www.poetryfoundation.org/

Roach, P. (1991). English phonetics and phonology. $2^{\text {nd }}$ ed. Cambridge: Cambridge University Press.

Rollison, D.J. (2003). The poem on the page: Graphical prosody in postmodern American poetry. In An interdisciplinary annual of textual studies, 15, p. 291-303.

Suppes, P. (2009). Rhythm and meaning in poetry. In Midwest studies in philosophy. New York: Wiley, 23, p.159-166.

Unconventional poetry. Available at:

http://hellopoetry.com/words/76643/unconventional/poems/ 
Vorobyova, O.P. (2012). The taste of "Chocolate": Intermediality and emotional resonance. In Visnyk of Kyiv national linguistic university. Kyiv: Vydavnychyi tsentr KNLU, 1 (15), p. 5-11. / Vorobyova O.P. Smak "Shokoladu": Intermedial'nist' j emotsijnyj rezonans. In Visnyk Kyyivs'koho natsional'noho linhvistychnoho universytetu. Kyiv: Vydavnychyi tsentr KNLU, 1 (15), s. 5-11. / Воробйова О.П. Смак "Шоколаду": Інтермедіальність й емоційний резонанс. In Вісник Київського національного лінгвістичного університету. Серія: Філологія. Київ: Видавничий центр КНЛУ, 1 (15), с. 5-11.

Vrabel, T. (2009). Lectures in theoretical phonetics of the English language and method guides for seminars. Ungvar: PoliPrint.

Zellner Keller, B. \& Keller, E. (Forthcoming). Representing speech rhythm. In Working Papers of COST 258. Lausanne: Université de Lausanne. Available at: http://citeseerx.ist.psu.edu/viewdoc/download?doi=10.1.1.34.9138\&rep=rep1\&type= $\underline{\mathrm{pdf}}$

\begin{tabular}{|l|l|l|}
\hline \multicolumn{1}{|c|}{ Contact data } & \multicolumn{2}{c|}{ Fields of interest } \\
Inna Zabuzhanska \\
CSc. (Philology), \\
Teacher at the Chair of \\
English Philology,
\end{tabular}

\section{Résumé in English}

The present paper discusses the issue of rhythmicity in American postmodern poetic texts, voiced by their authors. The research is aimed at investigating a set of physical parameters - fundamental frequency, duration, and intensity of rhythmic groups, syntagmas, and intrastressed intervals - drawn together to constitute speech rhythm in 
voiced American postmodern poetic texts. The topicality of the paper is predetermined by the material of the investigation, which is devoid of versification, rhyme, and has a non-traditional graphic layout of the text, including a wide range of fonts, rejection of capitalization, different punctuation design, noticeable indentation, spaces, etc. The analysis refutes the claim that speech rhythm is regarded as a roughly alternating pattern of stressed and unstressed syllables. The results also support the view that metrics as statistical measures are left behind and metrical expectancy can be excluded as a factor in creating postmodern poetry, as well as the presence of rhyme. The study reveals that in American postmodern poetry speech rhythm is only affected by such factors, as meter, rhyme, and graphic design of the poetic text. Rhythm participates in creating a cumulative image of the poetic text and helps the listener perceive and also interpret the author's intention. The paper also highlights the arrhythmic character of American postmodern poetic texts. There are grounds to think that the violation of the periodic alternation of pitch contours, maximum and minimal indicators of intensity, and relative isochrony of rhythmic units is deliberately done by the poet. The arrhythmicity mirrors the poet's desire to draw the listener's attention to the fundamental ideas of the poem.

Key words: rhythm, rhythmic group, poetic text, postmodernism, stress, pitch, intensity, duration.

\section{Résumé in German}

In diesem Artikel wird das Problem des Sprachrhythmus in amerikanischen postmodernen Poesietexten betrachtet, die von ihren Autoren vorgetragen wurden. Der Zweck der Forschung ist es, drei grundlegende physikalische Parameter zu untersuchen, und zwar Grundfrequenz, Dauer und Intensität der rhythmischen Gruppen, Syntagmas, und Intervalle, die zusammen den Sprachrhythmus der amerikanischen postmodernen poetischen Texten auf dem akustischen Niveau bilden. Die Art der Untersuchung wird durch die Eigenschaften des zu studierenden Materials vorgegeben: Es gibt keine Versifizierung und Reim, die grafische Gestaltung des 
Textes ist unkonventionell, einschließlich eine breite Palette von Fonts, Abwesemjeot von Kapitalen, verschiedene Zeichensetzung, auffälliges Einrücken usw. Die genannten Faktoren beeinflussen zwangsläufig den Klang des poetischen Textes. Die Fallstudie widerlegt die Behauptung, dass es sich beim Sprachrhythmus um den Wechsel von betonten und unbetonten Silben in der modernen amerikanischen Poesie handelt. Die Ergebnisse unterstützen auch die Ansicht, dass die Metrik als eine statistische Größe keine Rolle spielt, und die Erwartung des metrischen Schemas als ein Faktor bei der Schaffung von postmodernen Dichtungen bei Seite gelassen werden kann. Das gleiche gilt für die Anwesenheit von Reim. Die durchgeführte Analyse zeigt, dass in der amerikanischen postmodernen Poesie der Sprachrhythmus durch solche Faktoren wie Metrum, Reim und grafische Gestaltung des poetischen Textes beeinflusst wird. Der Artikel betont auch, dass poetische Texte des amerikanischen Postmodernismus arrhythmisch sein können. Man kann behaupten, dass die Verletzung des periodischen Wechsels von melodischen Konturen, die maximalen und minimalen Indikatoren von Intensität und relative Isochronie von rhythmischen Einheiten vom Dichter beabsichtigt wird. Arrhythmie wiederspiegelt den Wunsch des Dichters, die Aufmerksamkeit des Zuhörers auf die Grundgedanken des Gedichts zu lenken.

Stichwörter: Sprachrhythmus, Rhythmusgruppe, poetischer Text, Postmodernismus, Akzentuierung, Grundfrequenz, Intensität, Dauer, Arrhythmie.

\section{Résumé in French}

L'article est consacré à l'examen de la rythmicité des textes poétiques postmodernes américains lus par leurs auteurs. L'objectif de la recherche consiste à étudier les trois paramètres physiques de base, à savoir la fréquence fondamentale, la durée et l'intensité des groupes rythmiques, des syntagmes et des intervalles entres les accents, qui créent le rythme verbal au niveau acoustique dans un texte poétique postmoderne américain. L'article doit sont pertinence au matériel d'études privé de versification, de rythme et possédant une composition graphique du texte non-traditionnelle, y compris le recours à une large variété de polices, l'utilisation de seules lettres majuscules ou le refus total d'en utiliser quelques unes, des signes de ponctuation divers ou leur absence, des 
retraits et des espaces blancs bien visibles, etc. Tous ces facteurs influencent incontestablement la lecture du texte poétique à haute voix. Les resultats obtenus contestent la thèse que le rythme verbal de la poésie moderne américaine consiste en alternance des syllabes accentuées et inaccentuées. Les résultats confirment également l'opinion que la métrique comme mésure statistique est dépassée et l'attente d'un schéma métrique peut être exclue en tant que facteur de création de la poésie postmoderne. Il en est de même pour la présence d'une rime. L'étude démontre que le rythme verbal de la poésie postmoderne américaine est influencé par les facteurs comme mètre, rime et présentation graphique du texte poétique. L'article attire l'attention sur l'éventuelle absence de rythme dans les textes poétiques du postmodernisme américain. Tout laisse croire que l'irrégularité de l'alternance périodique des contours mélodieux, des indices maximaux et minimaux d'intensité et de l'isochronie relative des unités rythmiques est volontaire. L'arythmie traduit l'intention du poète d'attirer l'attention de l'auditeur aux idées fondamentales d'une poésie. Le rythme verbal participe à la création de l'image complète d'un texte poétique et favorise la perception et l'interprétation de l'intention d'auteur par l'auditeur.

Mots-clés: rythme, groupe rythmique, texte poétique, postmodernisme, accent, fréquence de l'accent principal, intensité, durée.

\section{Résumé in Russian}

В настоящей статье рассматривается проблема ритмичности в американских постмодернистских поэтических текстах, озвученных их авторами. Цель исследования состоит в изучении трех базовых физических параметров фундаментальную частоту, продолжительность и интенсивность ритмических групп, синтагм и междуударных интервалов, которые формируют речевой ритм на акустическом уровне в озвученном американском постмодернистском поэтическом тексте. Актуальность статьи предопределяется материалом исследования, который лишен стихосложения, рифмы и имеет нетрадиционную графическую компоновку текста, в том числе широкий спектр шрифтов, 
написания слов сплошными прописными или же полный отказ от прописных, различные знаки пунктуации или их отсутствие, заметные отступы, пробелы и т.п. Вышеупомянутые факторы непременно влияют на озвучивание поэтического текста. Полученные результаты опровергают утверждение о том, что речевой ритм рассматривается как чередование ударных и безударных слогов в современной американской поэзии. Результаты также подтверждают мнение о том, что метрика как статистическое измерение остается позади, и ожидание метрической схемы может быть исключено как фактор создания постмодернистской поэзии. Это же касается и наличия рифмы. Исследование показывает, что в американской постмодернистской поэзии речевой ритм находится под влиянием таких факторов, как метр, рифма и графический дизайн поэтического текста. В статье подчеркивается, что поэтические тексты американского постмодернизма могут быть аритмичными. Есть основания полагать, что нарушение периодического чередования мелодических контуров, максимальных и минимальных показателей интенсивности и относительной изохронности ритмических единиц делается поэтом сознательно. Аритмичность отражает стремление поэта привлечь внимание слушателя к фундаментальным идеям стихотворения. Речевой ритм участвует в создании совокупного образа поэтического текста и помогает слушателю воспринять, а также интерпретировать авторский замысел.

Ключевые слова: ритм, ритмическая группа, поэтический текст, постмодернизм, ударение, частота основного тона, интенсивность, продолжительность.

Article was received by the editorial board 05.11.17.

Reviewed 05.11.17. and 07.11.17.

Similarity Index 11\% 